\title{
Pili gemini
}

INSERM

\section{Source}

INSERM. (1999). Orphanet: an online rare disease and orphan drug data base. Pili gemini. ORPHA:79492

Pili gemini defines a situation where the papilla's tip of a hair follicle splits during the anagen phase and consequently grows two hair shafts emerging through a single pilary canal. A papilla tip that divides in several tips will produce several hair shafts, a situation named pili multigemini. Pili gemini or multigemini can occur in each type of hair. 